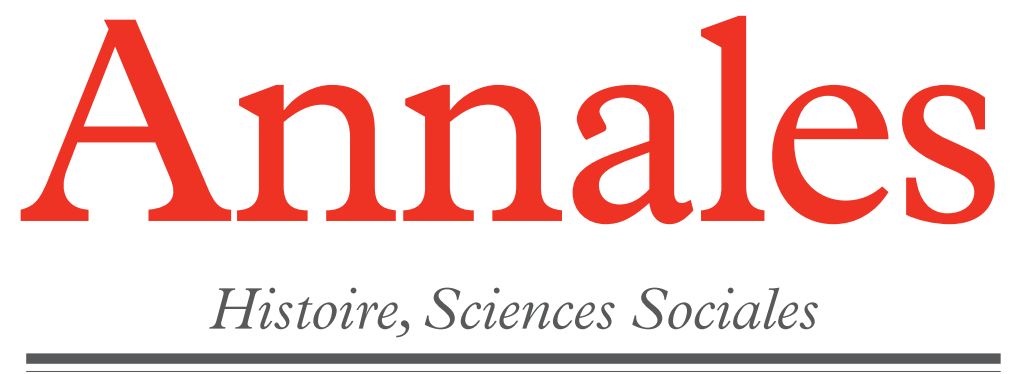

\title{
The Economics of Contemporary Africa
}

Agnès Labrousse

Denis Cogneau

Boris Samuel

\section{The History of Morocco}

Daniel Nordman

\section{Sociology, Creation, Action}

Fean-Louis Fabiani

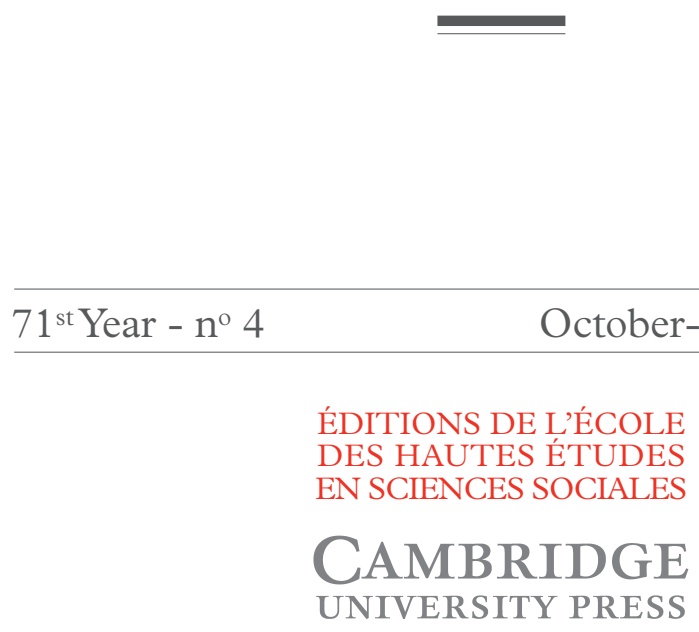




\section{Annales}

Histoire, Sciences Sociales

$71^{\text {st }}$ Year

no. 4 October-December 2016

\section{The Economics of Contemporary Africa}

Agnès Labrousse

Poor Numbers

Statistical Chains and the Political Economy of Numbers

Denis Cogneau

The Economic History of Africa: Renaissance or False Dawn?

Boris SAMUEL

Studying Africa's Large Numbers

\section{The History of Morocco}

Daniel NORDMAN

Of Space and Time: On a History of Morocco

\section{Sociology, Creation, Action}

Jean-Louis FABIANI

From the Arts to Action Theory

The Sociological Work of Pierre-Michel Menger

Abstracts 
This English edition of Annales HSS 71, no. 4 (2016) was published October-December 2017.

Editorial information online: http://annales.ehess.fr

Annales Editorial Office

EHESS, 105 boulevard Raspail 75006 Paris (France)

Tel.: +33 (0)153105377

E-mail: annales@ehess.fr

The French edition of the Annales is available in open access on the following platforms:

- Cairn (www.cairn.info/revue-annales.htm), from 2001, with a four-year delay

- Gallica (www.gallica.bnf.fr), from 1929 to 1938

- Persée (www.persee.fr/collection/ahess), 1929-1932, 1939-1941, and 1943-2002

and by subscription through:

- Cambridge Core (www.cambridge.org/annales), from 1929

- Jstor (www.jstor.org/journal/annahistscisoc), from 1929, with a five-year delay

The English edition of the Annales is available on the following platforms:

- Cairn international (www.cairn-int.info/journal-annales.htm), from 2012 to 2016

- Cambridge Core (www.cambridge.org/annales-in-English), from 2012 to current

- Revues.org (www.revues.org), from 2012 to 2016

From 2017, the Annales will be published in print and online by Éditions EHESS in partnership with Cambridge University Press. Subscriptions can be purchased through subscription agents or directly through Cambridge University Press:

Cambridge University Press (Journals)

University Printing House

Shaftesbury Road

Cambridge, CB2 8BS (UK)

journals@cambridge.org

Subscriptions begin with the first issue of the year. Prices and a subscription form can be found at the end of each issue and at www.cambridge.org/annales/subscribe-en.

Sale by issue (French edition only, France, Belgium, and Switzerland): $20 €$

Bookstore orders

CDE (Centre de diffusion de l'édition), 17 rue de Tournon 75006 Paris (France)

Distribution

SODIS, 128 avenue du Maréchal-de-Lattre-de-Tassigny 77400 Lagny-sur-Marne (France)

Sale by issue (international): contact Cambridge University Press

Layout: Michel Rohmer

(C) École des hautes études en sciences sociales, Paris, 2017

ISSN: 2398-5682 (English edition in print), 2268-3763 (English edition online) 


\section{Annales}

Histoire, Sciences Sociales

Founders: Marc Bloch and Lucien Febvre

Former Editor: Fernand Braudel

Quarterly review published since 1929 ,

edited by the École des hautes études

en sciences sociales with

the support of the Centre national

de la recherche scientifique,

the Florence Gould Foundation,

and the American University of Paris

\section{Advisory Board}

Mary Beard, Jane Burbank, Sandro Carocci, Jocelyne Dakhlia, Lorraine Daston, Marc Ferro, François Hartog, António Manuel Hespanha, Christian Lamouroux, Emmanuel Le Roy Ladurie, Alf Lüdtke, André Orléan, Sanjay Subrahmanyam, Pierre-François Souyri, Lucette Valensi

\section{Editor}

Étienne Anheim

\section{Editorial Board}

Vincent Azoulay, Romain Bertrand, André Burguière, Guillaume Calafat, Vanessa Caru, Jean-Yves Grenier, Camille Lefebvre, Antoine Lilti, Jacques Revel, Antonella Romano, Anne Simonin, Laurent Thévenot, Michael Werner

\section{Associate Editors for the English Edition}

Nicolas Barreyre, Stephen W. Sawyer

\section{Assistant Editors}

Aurianne Cox, Séverine Guiton, Chloe Morgan 